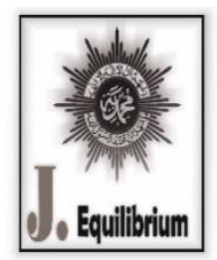

Equilibrium : Jurnal Pendidikan

Vol. IX. Issu 3. September-Desember 2021

Poosid Pendidikan sosiologi

http://journal.unismuh.ac.id/index.php/equilibrium

\title{
Eksistensi Budaya Pesta Sekolah di Desa Golo Lebo Kecamatan Elar Kabupaten Manggrai Timur
}

\author{
${ }^{1}$ Sriwahyuni; ${ }^{2}$ Muh Reski Salemuddin, ${ }^{3}$ Visensia H \\ ${ }^{1}$ Universitas Megarezky, Indonesia \\ Email : sriwahyunitiro@gmail.com \\ ²Universitas Megarezky, Indonesia \\ Email : muhrezkysalemuddin@gmail.com \\ ${ }^{3}$ Universitas Megarezky, Indonesia \\ Email : indah/vinsensiaindah@gmail.com
}

\begin{abstract}
Abstrak. Pendidikan di Indonesia masih merupakan investasi yang mahal sehingga diperlukan perencanaan keuangan. Pesta sekolah merupakan wujud dukungan dan bentuk kebersamaan masyarakat Manggarai yang sangat tinggi untuk membantu sesama yang mengalami kesulitan dalam membiayai pendidikan anak. Tujuan dari penelitian ini untuk mengetahui mengapa budaya pesta sekolah tetap dipertahankan sampai sekarang di Desa Golo Lebo Kecamatan Elar Kabupaten Manggrai Timur. Penelitian yang digunakan dalam penelitian ini menggunakan jenis kualitatif dengan pendekatan deskriptif. Penentuan informan pada penelitian ini menggunakan teknik snowball sampling. Pesta sekolah atau sering disebut wuat Wa'i ritual doa bersama saat seseorang atau anggota keluarga merantau (studi). Simbol yang dipakai saat acara (berdoa) yaitu dengan dibunuhnya seekor ayam putih sebagai silih persembahan. Dagingnya dimakan bersama dan bagian dalam ditaruh dalam wadah lalu diberikan kepada leluhur sebagai symbol bahwa mereka juga hadir dalam upacara tersebut dan selalu membimbing si calon perantau. dan harapan itu bisa disimbolkan dengan ungkapan lalong bakok du lakom lalong rombeng du kolem yang artinya pergi dengan sebuah harapan semoga pulang membawa keberhasilan. Dan jika si anak menyelesaikan kuliah kelak dan jika si anak menyelesaikan kuliah kelak maka dilakukan pula acara syukuran dengan menyembelih seeokor ayam hitam sebagai ungkapan syukur dan terimakasih kepada tuhan dan para leluhur yang telah melindungi dan membimbing si anaka selama menyelesaikan studinya ditanah rantau. Pesta sekolah masih tetap dipertahankan sampai saat ini di Desa Golo Lebo karena sangat bermanfaat bagi perkembangan anak, sebagai ajang memberikan nasihat bagi anak yang akan melanjutkan pendidikan serta sebagai pemupuk rasa persaudaraan/persatuan diantara warga masyarakat.
\end{abstract}

Kata Kunci : Eksistensi; Pesta Sekolah; Budaya; Persaudaran

Abstract. Education is still an expensive investment in Indonesia, so financial planning is required. Pesta sekolah is a form to support and the togetherness from the Manggarai community to help others who have difficulties in funding their son and girl in education. The purpose of this research is to find out why the Pesta sekolah culture has been maintained until now in Golo Lebo Village, Elar District, East Manggrai Regency. The research used qualitative type in a descriptive approach. Determination of informants in this study using snowball sampling technique. Pesta sekolah or often called wuat Wa'i ritual prayers together when someone or family members migrated (study) to the other place/city. The symbol used during the event (prayer) is to slaughter a white chicken as an offering. The meat was eaten together and the inside is put in a container and then given to the ancestors as a symbol that they are also present at the ceremony and always guide the prospective nomad, and that hope can be symbolized by the expression lalong bakok du lakom lalong rombeng du kolem which means to go with a hope that the return will 
bring success. And if they finishes college later, a thanksgiving event will also be held by slaughtering a black chicken as an expression of gratitude and gratitude to God and the ancestors who had protected and guided them while completing their studies in out of their land. Pesta sekolah is still being maintained until now in Golo Lebo Village because they are very beneficial for their development, as a place to provide advice for them who will continue their education and as a fostering a sense of brotherhood / unity among community members.

Keywords : Existence; Pesta Sekolah; Culture; Brotherhood

\section{PENDAHULUAN}

Indonesia sebagai bangsa yang plural terdiri dari beragam pulau dan budaya yang mencirikan identitas wilayah masing-masing. Kebudayaan bangsa Indonesia adalah kekayaan bangsa yang sesuai kodratnya memiliki kekuatan hidup yang berkembang menopang pembangunan nasional. Beragam kebudayaan ini merupakan perpaduan yang didukung oleh komposis keindahan dan kodratnya masingmasing, central issues related to our present understanding of culture and individual identity which are relevant to education (Bekerman, Z. (2007). Culture is the values and assumption that shapes the members (Deal, T. E., \& Peterson, K. D. (2010) are incorporated with them in a common cultural life" (Park and Burgess 1921 as cited in (Qian, L. (2017). (Banban, D. (2018). Zuo and Zillante (2005) in (Samaraweera, A., Senaratne, S., \& Sandanayake, Y. (2017) describe construction project culture as shared beliefs, values and basic assumptions, which determine the way the project is processed and the nature of relationships to be built up among members (Hargreaves, D., 2011, Kubat, A., 2018). Budaya sekolah merupakan kultur organisasi yang berada dalam lingkup sekolah. Budaya sekolah bukan hanya refleksi dari sikap para personil sekolah, namun juga merupakan cerminan kepribadian sekolah yang ditunjukkan oleh perilaku individu dan kelompok dalam sebuah komunitas sekolah (Daryanto \& Tarno, 2015 as cited in Puspasari, A., \& Muhroji, M., 2019).

Budaya tersebut sebagai komponen yang dapat mempengaruhi kualitas kehidupan yang berkembang berdasarkan nilai, norma, dan kebiasaan yang di anut dan dibudayakan sekolah. Hal ini warga sekolah memiliki peran penting dalam pengembangan budaya sekolah tersebut karena budaya sekolah memiliki peran penting yang menjadi faktor esensial dalam membentuk karakter siswa menjadi manusia yang memiliki kecakapan personal dan akademik. Kodrat yang membuat perbedaan, keanekaragaman, adalah rahmat yang mendorong tumbuhnya saling pengertian untuk saling memahami dan saling menghormati satu sama lain. Dengan kesadaran berbeda itu, timbul kehendak untuk saling menolong dan saling memerlukan dalam satu kehidupan yang ditopang oleh cita-cita bersama menjadi suatu bangsa dengan kebudayaan yang amat kaya. Pendidikan secara praktis tidak dapat dipisahkan dari nilai-nilai budaya.

Dalam UU Sisdiknas No 20 tahun 2003, Pendidikan adalah usaha sadar dan terencana untuk mewujudkan suasana belajar dari proses pembelajaran agar peserta didik secara aktif mengembangkan potensi dirinya untuk memiliki kekuatan spiritual keagamaan, pengendalian diri, kecerdasan, akhlak mulia, serta keterampilan yang diperlukan dirinya dan masyarakat. Pendidikan juga merupakan proses penyadaran terhadap tindakan manusia dimana dia hidup. Menyadari pentingnya pendidikan maka banyak anak berharap agar dapat mengenyam pendidikan formal setinggi-tingginya. Akan tetapi realitanya, pendidikan di Indonesia masih merupakan investasi yang mahal sehingga diperlukan perencanaan keuangan (Zainal Arifin, 2014:21), (Kobayashi, Y., 2018).

Pada artikel ini menguraikan tentang pesta sekolah. Pesta sekolah dapat dikatakan sebagai bentuk dukungan sosial dari masyarakat baik dalam bentuk materil maupun moril kepada individu yang ingin melanjutkan studi. Dukungan sosial merupakan kenyamanan psikis dan emosional yang diberikan kepada individu oleh keluarga, teman, rekan, dan yang lainnya, dapat juga berupa pertukaran interpersonal dimana salah seorang memberikan bantuan atau pertolongan kepada yang lain (Toding, 
David dan Pali, 2015 as cited in Nanu, F. N. A., Anakaka, D. L., \& Pello, S. C, 2019). Acara ini dilakukan karena berangkat dari kesadaran masyarakat Manggarai akan pentingnya pendidikan. Namun karena terkendala biaya pendidikan yang besar serta ketidakmampuan ekonomi masyarakat saat itu maka diadakan pesta sekolah.

Pesta sekolah sebagai bentuk dukungan sosial diasumsikan berpengaruh terhadap timbulnya motivasi seseorang karena nilai-nilai yang tertuang dalam pesta sekolah sarat akan makna, seperti nasihat-nasihat yang disampaikan oleh tua adat kepada anak yang ingin melanjutkan studi mengisyaratkan adanya dukungan sosial berupa moril dari seluruh anggota masyarakat agar anak yang melanjutkan studi bisa berhasil. Selain itu pemberian uang saat acara pesta sekolah mengisyaratkan. Adanya dukungan sosial berupa materil dari anggota masyarakat kepada anak yang ingin melanjutkan studi. Alasan pesta sekolah tetap dipertahankan sampai saat ini karena memiliki beberapa alasan yaitu: a) Pesta sekolah sangat bermanfaat bagi perkembangan pendidikan anak, b) Pesta sekolah merupakan ajang memberikan wejangan bagi anak yang sudah maupun akan melanjutkan pendidikan, c) Pesta sekolah sebagai pemupuk rasa persaudaraan/persatuan diantara warga masyarakat. 2) Budaya pesta sekolah bisa menjadi modal sosial bagi masyarakat karena, a) adanya semangat komunalisme yang berkembang dalam masyarakat, b) kegiatan pesta sekolah yang sangat mengutamakan lonto leok (duduk bersama) (Mahesti, I., \& Awaru, M. R. S. (2017). Pesta Sekolah is a form of social support in the Manggarai community which is reflected in the form of caring and assistance both morally and materially to fellow members (Nanu, F. N. A., Anakaka, D. L., \& Pello, S. C., 2019).

This article is supported by some results of research howed that the main problem that causes local wisdom culture pesta sekolah ineffective encourages students get into college is "cultural injustice where the culture pesta sekolah is only a benefit for the rich community group. The recommendation on this study is the development of social arisan pesta sekolah as an alternative for strengthening pesta sekolah. Secondly, the need for government intervention to repair facilities of education to reduce poverty problem. (Yovan, S., Fil, S., \& Pramusinto, A. (2012). Pesta sekolah merupakan wujud dukungan dan bentuk kebersamaan masyarakat Manggarai yang sangat tinggi untuk membantu sesama yang mengalami kesulitan dalam membiayai pendidikan anak. Pesta sekolah mempunyai arti sebagai suatu acara perjamuan yang dilakukan dengan tujuan untuk mendapatkan atau mengumpulkan dana untuk membantu membiayai pendidikan. Acara ini juga dipandang sebagai sebuah tradisi, karena merupakan kesepakatan bersama di Kabupaten Manggarai umumnya. Hal ini mempunyai makna bahwa dalam kehidupan bersama ada rasa kebersamaan, saling ketergantungan antara yang satu dengan yang lain dalam meringankan beban bersama. Tetapi tidak semua mahasiswa Manggarai yang melanjutkan studi dengan menggunakan uang hasil pesta sekolah tersebut menyelesaikan studi tepat waktu di perguruan tinggi. Ada yang lulus tidak tepat waktu dan bahkan ada yang drop out dari perguruan tinggi. Selain itu pemanfaatan uang yang tidak sesuai dengan kebutuhan belajar juga mempengaruhi prestasi mahasiswa tersebut di perguruan tinggi.

Peneliti tertarik untuk meneliti tentang sejauh mana usaha masyarakat dalam mempertahankan dan tetap melestarikan budaya pesta sekolah, mengingat budaya ini sangat berperan dalam memajukan pendidikan dan Masyarakat Desa Golo Lebo kecamatan Elar kabupaten Manggarai Timur Nusa Tenggra Timur masih memelihara budaya pesta sekolah.

\section{METODE PENELITIAN}

Penelitian yang digunakan dalam penelitian ini menggunakan jenis kualitatif dengan pendekatan deskriptif. Penelitian kualitatif deskriptif yaitu penelitian berusaha untuk menemukan pemecahan masalah yang ada sekarang berdasarkan data-data, juga menyajikan data, menganalisis dan menginterpetasi. (Gunawan, 2013:78) Yaitu yang diperoleh melalui observasi serta berbagai keterangan 
atau masukan dari informan melalui wawancara yang mendalam. Informan sendiri merupakan orang yang dimanfaatkan untuk memberi informasi tentang situasi dan kondisi latar penelitian. Penentuan informan pada penelitian ini menggunakan teknik snowball sampling. Snowball sampling adalah metode guna mengidentifikasi dan mengambil sampel lewat suatu jaringan. Snowball sampling didasarkan pada analogi bola salju, yang dimulai dalam ukuran kecil, tetapi seiring proses, jumlahnya membesar. Snowball sampling adalah teknik multi tahap. la dimulai dengan sedikit orang dan membesar sehubungan dengan pergerakan penelitian.

Berdasarkan teknik snowball sampling tersebut, maka ada beberapa kriteria yang berlaku bagi pemilihan informan. Beberapa kriteria tersebut adalah sebagai berikut: Informan merupakan penduduk asli Desa Golo Lebo, Informan banyak mengetahui tentang budaya pesta sekolah, dan Informan pernah melakukan/melaksanakan budaya pesta sekolah. Selanjutnya dari data sekunder, berbagai teori dan informasi yang diperoleh tidak langsung dari sumbernya yaitu berupa buku, dokumen, dan tulisan mengenai eksitensi budaya pesta sekolahdan juga data lainnya yang relevan dengan kebutuhan dan tujuan penelitian. Fase terpenting dari penelitian adalah pengumpulan data. Observasi adalah pengamatan terhadap suatu objek yang diteliti baik secara langsung maupun tidak langsung untuk memperoleh data yang harus dikumpulkan dalam penelitian. Secara langsung adalah terjun ke lapangan terlibat seluruh pancaindra.

Secara tidak langsung adalah pengamatan yang dibantu melalui media visual/audiovisual. (Djam'an Satori dan Aan Komariah, 2012:103). Wawancara merupakan salah satu teknik pengumpulan data yang dilakukan dan berhadapan langsung dengan pihak atau orang yang diwawancarai. Pada saat wawancara ini dapat juga diberikan daftar pertanyaan yang terlebih dahulu untuk dijawab pada kesempatan lain. Metode wawancara merupakan metode yang digunakan untuk mengumpulkan data atau keterangan lisan dari sesorang yang disebut responden melalui suatu percakapan yang sistematis dan terorganisasi. Teknik wawancara yang digunakan dalam penelitian ini adalah wawancara mendalam. Wawancara mendalam (in depth interview) adalah proses memperoleh keterangan untuk tujuan penelitian dan cara tanya jawab sambil bertatap muka antara pewawancara dan informan (Ulber Silalahi, 2012:312).

Instrument dalam penelitian ini yaitu peneliti bertindak sebagai instrument sekaligus pengumpulan data. Peran peneliti yaitu sebagai pengamat penuh dan kehadiran peneliti diketahui statusnya sebagai peneliti oleh subjek atau informan. Peneliti sebagai instrument juga harus divalidasi seberapa jauh validasi terhadap pemahman metode kualitatif, penguasaan wawasan terhadap bidang yang diteliti, kesiapan peneliti untuk masuk objek penelitian, baik secara akademik maupun logistik.

Data yang diperoleh dilapangan kemudian diolah secara deskriptif kualitatif dengan melalui tiga tahap, yaitu; Reduksi data diartikan sebagai proses pemilihan, pemusatan perhatian pada penyederhanaan, pengabstraksian, dan transformasi data kasar yang diperoleh dari catatan-catatan tertulis dilapagan. Kegiatan reduksi akan berlangsung terus-menerus selam proses pengumpulan data berlangsung. Reduksi data juga merupakan bentuk analisis yang mempertajam, memilih, memfokuskan, membuang dan menyusun data dalam suatu cara sehingga kesimpulan akhir dapat digambarkan dan diverifikasikan. Kedua Penyajian Data, yaitu langkah kedua dari proses analisis data kualitatif adalah penyajian data, yaitu sekumpulan informasi yang memungkinkan penarikan kesimpulan dan pengambilan tindakan. Melalui data yang disajikan kita dapat melihat dan memahami apa yang sedang terjadi dan apa yang harus dilakukan. Bentuk yang paling sering digunakan dalam penyajian data kualitatif adalah teks naratif. Dan yang ketiga adalah Penarikan Kesimpulan, yaitu dari permulaan pengumpulan data penelitian kualitatif kemudian memusatkan apakah makna sesuatu, mencatat keteraturan, pola penjelasan, sampaimeningkat menjadi eksplisit dan mendasar sehingga menjadi suatu kesimpulan yang bersifat induktif. 


\section{HASIL PENELITIAN DAN PEMBAHASAN}

Berdasarkan hasil survei lapangan di Desa Golo Lebo Kecamatan Elar, adapun beberapa alasan yang melatarbelakangi budaya pesta sekolah tetap dipertahankan sampai saat ini yaitu:

Untuk memenuhi kebutuhan. Pendidikan tidak serta-merta membebaskan mereka dari problem keuangan yang dibutuhkan membiayai pendidikan itu sendiri. Kehadiran pesta sekolah menjadi salah satu sarana bagi pemenuhan kebutuhan hidup masyarakat Desa Golo Lebo, terutama kebutuhan masyarakat dalam mengakses pendidikan anak. Pesta sekolah merupakan arisan dan bentuk kerjasama masyarakat dalam meringankan biaya pendidikan. Tidak dapat dipungkiri bahwa pesta sekolah menjadi faktor pendukung bagi keberlangsungan pendidikan anak-anak yang melanjutkan pendidikan di perguruan tinggi di Desa golo Lebo.

Orang tua yang menyekolahkan anak di perguruan tinggi tentu saja merasa sangat dibantu dengan adanya pesta sekolah. Beban keuangan yang ditanggung oleh orang tua menjadi lebih ringan, dan tentu saja bantuan yang diberikan oleh pihak keluarga dan kerabat menjadi motivasi bagi mereka sehingga lebih bersemangat dalam mencari uang untuk membiayai pendidikan. Bagi anak yang dipestakan pelaksanaan pesta sekolah juga melahirkan rasa tanggung jawab yang besar dalam diri mereka. Merasa mendapat dukungan dari banyak pihak, sehingga anak yang bersekolah ini akan menggunakan dana yang telah terkumpul pada acara pesta sekolah ini dengan sebaik-baiknya bagi keperluan pendidikan dan berusaha keras agar bisa menyelesaikan pendidikan tepat waktu.

Acara ini berdampak positif bagi perkembangan sumber daya manusia di Manggarai, terutama bagi masyarakat Desa Golo lebo. Hal ini terlihat bahwa banyak anak yang berhasil menyelesaikan studi sampai meraih gelar sarjana berkat pesta sekolah ini. Hal ini merupakan kebanggaan bagi masyarakat Desa Golo lebo. Hal ini terlihat bahwa banyak anak yang berhasil menyelesaikan studi sampai meraih gelar sarjana berkat pesta sekolah ini. Hal ini merupakan kebanggaan bagi masyarakat Desa Golo lebo. Dengan demikian kehadiran pesta sekolah sangat bermanfaat perkembangan pendidikan anak.

\section{a. Menjadi Patokan Bagi Masyarakat.}

Dalam acara pesta sekolah ini, suatu hal yang sangat penting yang harus diperhatikan anak adalah nasihat atau saran dari orang tua dan orang lain yang dituakan atau dianggap berpengaruh bagi masyarakat setempat. Nasihat atau wejangan dari orang tua itu sangat bermakna dan menjadi sumber patokan bertindak bagi anak. Mendapat dukungan yang begitu besar dari seluruh keluarga dan kerabat menjadi motivasi tersendiri bagi anak.

\section{b. Mewujudkan Nilai dan Norma dalam Masyarakat.}

Pesta sekolah merupakan salah satu ajang berkumpul bagi seluruh keluarga besar dan kerabat. Acara pesta sekolah merupakan semangat persaudaraan orang Manggarai lebih khususnya masyarakat Desa Golo Lebo sebagai suatu ikatan keluarga besar. Semangat persaudaraan yang lahir secara alami ini melahirkan semangat dan nilai gotong royong. Ketika mengamati perilaku sosial yng terdapat di masyarakat desa Kembang mekar dengan budaya pesta sekolah yang mereka jalankan maka dapat dipahami bahwa solidaritas yang terdapat pada masyarakat ini merupakan solidaritas yang bersifat mekanik. Alasan budaya pesta sekolah dapat menjadi modal sosial bagi masyarakat Desa Golo Lebo. Dengan adanya rasa tanggung jawab ini, maka anak akan menggunakan uang yang telah dikumpulkan dengan sebaik-baiknya bagi keperluan pendidikan dan bisa menyelesaikan pendidikan tepat waktu. Sedangkan bagi orang tua yang pernah menyelenggarakan pesta sekolah mereka menjadi lebih bersemangat lagi untuk mencari uang demi membiayai pendidikan anak karena tumbuh perasaan tidak 
mau untuk selalu dibantu serta bergantung pada orang lain. Jadi, pesta sekolah tetap dipertahankan karena sangat bermanfaat bagi perkembangan pendidikan anak. Pesta sekolah telah memberikan sumbangan yang sangat besar bagi pendidikan terutama bagi individu dan orang tua yang menyekolahkan anak-anaknya.

Herbert George Blumer (teori interaksionisme simbolik) menurutnya istilah interaksionisme simbolik menunjuk kepada sifat khas dari interaksi antar manusia. Proses interaksi manusia itu bukan suatu proses dimana adanya stimulus secara otomatis dan langsung menimbulkan tangggapan atau respon. Tetapi antara stimulus yang diterima dan respon yang terjadi sesudahnya, diantarai oleh proses interpretasi oleh individu atau kelompok.Jelas proses interpretasi ini adalah proses berpikir yang merupakan kemampuan yang khas yang dimiliki manusia. Proses interpretasi yang menjadi penengah antara stimulus dan respon menempati posisi kunci dalam teori interaksionisme simbolik. Proses kehidupan masyarakat terjadi menurut pandangan teori interaksionisme simbolik secara sederhana dapat digambarkan sebagai berikut. Individu atau unit-unit tindakan yang terdiri atas sekumpulan orang tertentu, saling menyesuaikan atau saling mencocokan tindakan mereka satu dengan yang lainnya melalui proses interpretasi.

Budaya pesta sekolah merupakan salah satu budaya yang dalam pelaksanaannya terjadi karena melalui proses interaksi antar sesama manusia. Dalam hal ini melibatkan individual, interaksi dan komunikasi. Disini tidak ada batasan antar budaya dan komunikasi, yang artinya budaya adalah komunikasi dan komunikasi adalah budaya. Pada akhirnya, acara pesta sekolah yang sudah dilakukan selama puluhan tahun patut dipertahankan dan diwariskan kepada generasi penerus, karena nilai-nilai yang terkandung dalam pesta sekolah seperti persaudaraan, cinta kasih, gotong royong, dan semangat pengorbanan merupakan dorongan dan sumber motivasi awal bagi mahasiswa yang ingin melanjutkan pendidikan di perguruan tinggi. Melalui pesta sekolah, keinginan masyarakat Desa Golo Lebo untuk sukses tidak sebatas angan, tetapi dapat terwujud berkat dukungan sosial masyarakat Manggarai. Merujuk pada istilah dalam tutur bahasa Manggarai yakni Muku Ca Puu Neka Woleng Curup. Teu Ca Ambong, Neka Woleng Lako atau secara umum dapat diartikan Satu dalam Perkataan, Satu dalam Perbuatan (Mahesti, I., \& Awaru, M. R. S. (2017). Nilai kebersamaan dan saling membantu dalam meringankan biaya pendidikan yang tetap dijunjung tinggi dalam masyarakat menciptakan interaksi yang intim dan akrab (). Komunalisme merupakan hasil dari kerjasama, mengembangkan kepercayaan dan membangun jaringan. Semangat komunalisme sama dengan menyusun lingkungan yang kaya akan partisipasi dan peluang. Sehingga menciptakan sebuah lingkungan yang memungkinkan setiap pelaku untuk sering bertemu. Hal ini lalu melahirkan hubungan yang berkelanjutan dan frekuensi perilaku timbal balik.

\section{KESIMPULAN}

Menghadapi kehidupan yang serba modern pada saat ini, kita harus kita harus bijak dalam memilih maupun memilah sikap dan perilaku. Masyarakat kita yang pada zaman dahulu sangat mengutamakan musyawarah untuk mufakat jangan sampai hanya menjadi slogan bagi masyarakat kita masa kini. Oleh karena itu kita patut bangga dengan banyaknya warisan-warisan budaya yang penuh manfaat dan kaya akan nilai-nilai positif, misalnya budaya pesta sekolah. Pesta sekolah masih tetap dipertahankan sampai saat ini di Desa Golo Lebo karena sangat bermanfaat bagi perkembangan anak, sebagai ajang memberikan nasihat bagi anak yang akan melanjutkan pendidikan serta sebagai pemupuk rasa persaudaraan/persatuan diantara warga masyarakat. Melalui kerjasama mereka saling memberikan dukungan moril maupun materil baik bagi anak maupun bagi orang tua yang menyekolahkan anakanaknya. 


\section{DAFTAR PUSTAKA}

Achmadi, Asmoro. 2014. Filsafat Umum. Jakarta: PT Raja Grafindo Persada.

Arifin, Zainal. 2014. Sosiologi Pendidikan Pengertian, Tujuan, Ruang Lingkup dan Pendidikan Sebagai Kapital. Makassar: Anugrah Mandiri.

Arisandi, Herman. 2015. Buku Pintar Pemikiiran Tokoh-Tokoh Sosiologi Dari Klasik Sampai Modern. Yogyakarta: IRCiSoD

Banban, D. (2018). Harmony in diversity: an empirical study of harmonious co-existence in the multiethnic culture of Qinghai. International Journal of Anthropology and Ethnology, 2(1), 1-23) https://link.springer.com/article/10.1186/s41257-018-0010-6

Deal, T. E., \& Peterson, K. D. (2010). Shaping school culture: Pitfalls, paradoxes, and promises. John Wiley \&

https://books.google.co.id/books?hl=id\&lr=\&id=0y09hxoQA8oC\&oi=fnd\&pg=PT8\&dq=EXISTENCE +OF+SCHOOL+PARTY+CULTURE\&ots=rLifUSMqeA\&sig=c7wcbegJhuGFHhOgoz3qtSIYHMU\&redir e $\mathrm{sc}=\mathrm{y} \# \mathrm{v}=$ onepage $\& \mathrm{q} \& \mathrm{f}=\mathrm{false}$

Hargreaves, D. (2011). The challenge for the comprehensive school: culture, curriculum and community (Vol.

Routledge).

https://books.google.co.id/books?hl=id\&lr=\&id=AtFVhVV74EwC\&oi=fnd\&pg=PR3\&dq=SCHOOL+P ARTY+CULTURE\&ots=7MJy6LVfwr\&sig=n19pOUrXkpgiK9053SU3pioftmU\&redir esc=y\#v=onepage \&q=SCHOOL\%20PARTY\%20CULTURE\& $\mathrm{f}=$ false

Gunawan, Iman. (2013). Metode Pendidikan Kualitatif Teori dan Praktek. Jakarta: PT. Bumi Aksara.

Ibrahim, (2015). Metode Penelitian Kualitatif. Bandung: Alfabeta

Kobayashi, Y. (2018). The neo-liberal notion of global language skills vs. monolingual corporate culture: -existence or rivalry?. Journal of Multilingual and Multicultural Development, 39(8), 729739) https://doi.org/10.1080/01434632.2018.1438445.

Kubat, A. (2018). Morality as legitimacy under Xi Jinping: The political functionality of traditional culture for the Chinese Communist Party. Journal of Current Chinese Affairs, 47(3), 47-86) https://doi.org/10.1177/186810261804700303

Laksmi, (2017). Teori Interaksionisme Simbolik (jurnal) https://jurnal.iainsalatiga.ac.id /2017/01/Teori interaksionisme simbolik. Html, diakses 01 Oktober 2020.

Livinusingge. (2015). Ketika wuat wa'i pesta sekolah. (online). Https://livinusingge. blogspot. Co. id/2015/06/ketika wuat wa'i menjadi pesta sekolah diakses pada 02 februari 2020.

Mahesti, I., \& Awaru, M. R. S. (2017). Eksistensi Budaya Pesta Sekolah Di Desa Kembang Mekar Kecamatan Sambi Rampas Kabupaten Manggarai Timur Nusa Tenggara Timur. Jurnal Sosialisasi: Jurnal Hasil Pemikiran, Penelitian dan Pengembangan Keilmuan Sosiologi Pendidikan, 65-68) https://ojs.unm.ac.id/sosialisasi/article/view/12071

Martini, Euveniati. (2018). Persepsi Masyarakat Ranggu Manggarai Barat Terhadap Budaya Pesta Sekolah Sebagai Upaya Penggalangan Dana Pendidikan. Skripsi Fakultas Keguruan Dan Ilmu Pendidikan Universitas Sanata Darma Yogyakarta. Diakses pada 11 Mei 2020

Nanu, F. N. A., Anakaka, D. L., \& Pello, S. C. (2019). Dukungan Sosial dalam Bentuk Pesta Sekolah dengan Motivasi Berprestasi Mahasiswa Manggarai. Journal of Health and Behavioral Science, 1(1), 47-58) DOI: https://doi.org/10.35508/jhbs.v1i1.2082

Nggoro, A. M. (2014). Filosofi Wuat Wa'i Budaya Manggarai Dari Perspektif Demokrasi Pancasila. Jurnal Penelitian STKIP. St. Paulus Ruteng. Diakses pada 02 Februari 2020

Normina. (2017). Pendidikan dalam kebudayaan. (jurnal) https://jurnal.uin/antasari.ac.id/2017/28/Pendi dikan dalam kebudayaan. Html, diakses 18 februari 2020.

Puspasari, A., \& Muhroji, M. (2019). Prathom School Culture: Implementasi Pengembangan Budaya Sekolah Berbasis Islam Di Thailand. In Prosiding Seminar Nasional Pagelaran Pendidikan Dasar 
$\begin{array}{lllllll}\text { Nasional } & \text { (PPDN) } 2019 \text { (Vol. } & 1, & \text { No. } & 1, & \text { pp. } & \text { 41-53) }\end{array}$ http://seminar.uad.ac.id/index.php/ppdn/article/view/1340/637.

Qian, L. (2017). Three Types of Social Integration Status among Children of Migrant Workers in China: Scenes of Superiority of City Residents, Co-Existence of Urban Culture and Rural Hometown Culture, and Weak Social Capital under Strong Policy Discourse. Chinese Education \& Society, 50(4), 393-408) https://sci-hub.se/https://doi.org/10.1080/10611932.2017.1382132.

Rahayu, Osin. (2016). Tradisi Wuat Wa'i Pada Masyarakat Manggarai. Skripsi Fakultas Ilmu Sosial Universitas Negeri Makassar. diakases pada 02 Februari 2020

Ritzer, George. (2016). Sosiologi Ilmu Pengetahuan Berparadigma Ganda. Jakarta: PT Raja Grafindo Persada

Samaraweera, A., Senaratne, S., \& Sandanayake, Y. (2017). Nature of existence of public sector construction project culture: an exploratory case study. In Proceedings of The 6th World Construction Symposium 2017: What's New and What's Next in the Built Environment Sustainability Agenda? 30 June-2 July 2017, Colombo, Sri Lanka (pp. 308-315). https://www.researchgate.net/profile/Aparna-

Samaraweera/publication/321161913 NATURE OF EXISTENCE OF PUBLIC SECTOR CONSTRUCT ION PROJECT CULTURE AN EXPLORATORY CASE STUDY/links/5a129f87aca27287ce2a8e37/NA TURE-OF-EXISTENCE-OF-PUBLIC-SECTOR-CONSTRUCTION-PROJECT-CULTURE-AN-EXPLORATORYCASE-STUDY.pdf 